\title{
OPENCV ALAPÚ TÁBLAFELISMERŐ VIDEÓELEMZŐ SZOFTVER LÉTREHOZÁSA
}

\section{THE IMPLEMENTATION OF AN OPENCV-BASED TRAFFIC SIGN IDENTIFIER VIDEOANALYST SOFTWARE}

\author{
Balázs Viktor ${ }^{1}$, Szilágyi László ${ }^{2}$, Apagyi Antal $^{3}$, Erdei Timotei István ${ }^{4}$ \\ ${ }^{1}$ Debreceni Egyetem, Informatikai Kar, Debrecen, Magyarország, \\ groolue@gmai.com \\ ${ }^{2}$ Debreceni Egyetem, Informatikai Kar, Debrecen, Magyarország, szi- \\ szi610@gmail.com \\ ${ }^{3}$ Debreceni Egyetem, Müszaki Kar, Mechatronikai Tanszék, 4028 Magyarország, \\ Debrecen, Ótemető utca 2-4., (52) 415 155, apagyi.toni@gmail.com \\ ${ }^{4}$ Debreceni Egyetem, Müszaki Kar, Mechatronikai Tanszék, 4028 Magyarország, \\ Debrecen, Ótemetö utca 2-4., (52) 415 155, timoteierdei@gmail.com
}

\begin{abstract}
Nowadays, accidents tend to happen because our attention is being split up by the ever-growing influx of information, losing the focus from the driving, traffic signs, and other signals. The consequences of these minor or major accidents weight down on our shoulders. During our project, we tried to eliminate, or help this issue, using present technology, improving upon that, trying to avoid these accidents. Our task consisted on implementing a software, that could identify traffic signs from any video streams.
\end{abstract}

Keywords: OpenCV, $\mathrm{C}^{++}$, traffic signs, video, computer vision, Industry 4.0.

\section{Összefoglalás}

A napjainkban történt autóbalesetek sok esetben azért történnek/történhettek meg, mivel figyelmünket a folyamatosan növekvő információáradat túlzottan megosztja, így nem vagyunk képesek teljesen a vezetésre, útjelző táblákra, egyéb jelzéskere koncentrálni. Az így bekövetkezett kisebb koccanások, vagy súlyos balesetek következményei minket terhelnek. Erre a problémára próbáltunk megoldást találni projektünk során, felhasználva a már meglevő technológiát, és azokat tovább fejlesztve törekedjünk ezen eseményeket elkerülni. A feladat során szoftverünkkel közúti jelzőtáblákat felismerni bármilyen videófelvételről.

Kulcsszavak: OpenCV, C++, jelzötábla, videó, gépi látás, Ipar 4.0.

\section{Bevezető}

A Debreceni Egyetem, Müszaki Karán kialakított, Épületmechatronikai Kutatóközpont biztosította az infrastruktúrát a képelemzési rendszerek megalkotásához, az elmúlt években [11]. A térfigyelő rendszerek kialakítása kulcsfontosságú vagyonvé- delem szempontjából, büncselekmények megelőzése érdekében [12].

A mai világban a képfeldolgozás nagy lépéseket tett fejlődés terén, ezért is választottuk ezt a projektet. A kezdeti kiindulási pont az alakzatdetektáló szoftver volt, amely képekről háromszög, kör, illetve sok- 
szög alakokat ismert fel és jelölt meg különböző színekkel, valamint elöre gondolva a további fejlesztésekre megkülönböztette a piros háromszög és a piros kör alakokat is [13].

Távlati céljaink között szerepelt, hogy ezt a szoftvert egy önvezető traktorban alkalmazva, azt városban, és közúton egyaránt képessé tenni közlekedésre, illetve táblák mellett elterjedt szőlőbetegségeket is észlelni tudjunk a szoftver segítségével.

A program fejlesztése során motivációként szolgált, hogy a Google, a Tesla, az Uber és nagyobb autógyártó cégek önjáró autók folyamatos tervezését és tesztelését végzik, amelyek egy része már forgalomban is debütált. A Google önjáró autóflottája ami Waymo néven fut - már több mint 3 millió mérföldet tett meg [1].

\section{Tervezési fázis és működési elv}

A projekt kezdetén az eddigi fejlesztések alatt elkészült program egésze felhasználásra került volna, de a tervezgetések és az ötletek megbeszélése során, teljesen új feature-ek kerültek hozzá adásra és néhány átdolgozásra.

A jelenlegi képelemző rendszerek egy része gépi tanulást alkalmaznak, mások elöre elkészített képi adatbázisból [14] keresik ki és jelölik meg a mozgóképen látott objektumokat [3]. A szoftverek kidolgozásakor sokszor figyelembe veszik az emberi idegrendszer és az agy feldolgozó képességét is [4].

$\mathrm{Az}$ elkészített program a beolvasott videófájlt framenként dolgozza fel, így olyan mintha gyors egymás után egy-egy fényképet elemezne. Ezeken a képeken párhuzamosan fut le a háromszög, kör illetve négyszög felismerő függvény.

A sokszögeket felismerő függvények a kapott képen található kontúrokkal dolgoznak, amíg a kör felismerése Hughtranszformáció segítségével történik. Az alakzat felismeréshez előzőleg a kapott képeket bináris képekké kell alakítani, ame- lyekre így már ráengedhető az alakzatdetektáló függvény rész.

A programba meghívott videofelvétel a teljesítmény miatt 640x360 felbontásra és 30képkocka/másodperces video formátumra lett konvertálva Freemake Video Converter használatával [5].

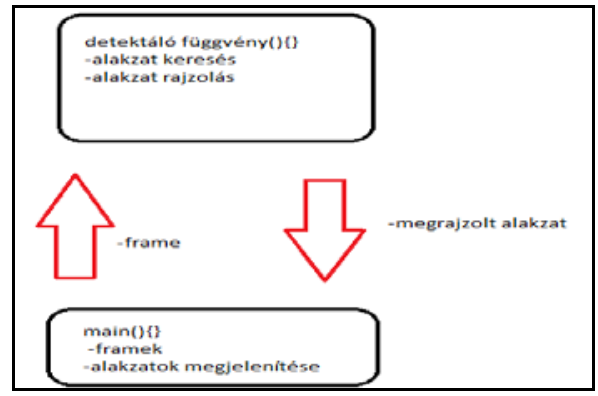

1. ábra. Müködési elv

\section{Felhasznált hardware és software}

A nagy számítási teljesítmény miatt, a projekt kidolgozása egy ASUS X550C típusú notebook-on lett végrehajtva. A számítógép Intel(R) Core(TM) i5-3337U @ 1.80GHZ CPU-val, 8GB DDR3 $1600 \mathrm{MHZ}$ memóriával és egy NVIDIA GeForce GT 720M videokártyával rendelkezik és maximum 1366 x 768 felbontást tud megvalósítani. A feladat elvégzése szempontjából kulcsfontosságú a VGA alapú képelemzés.

A számítógépen 64 bites Microsoft Windows 10 Home operációs rendszer futott. A program pedig Visual Studio 2015 fejlesztői környezetben $\mathrm{C}++$ nyelven íródott az OpenCV képfeldolgozó könyvtár segítségével [6]. Különböző video konvertáló szoftverek is alkalmazásra kerültek, hogy a megfelelő video bemenetet elő tudjuk állítani. Az OpenCV programot a használatához minden újonnan kezdet project file-ba integrálni kell. Ez a project Properties menüjében történik, ahol a $\mathrm{C} / \mathrm{C}++$ menüpontban meg adjuk az OpenCV fájlokat tartalmazó mappa elérési útvonalát, valamint a Linker menüpont alatt beállítjuk, hogy az elérési útvonalon melyik library fájl kerül felhasználásra. 
Továbbá az operációs rendszerünk globális környezeti változói között a PATH menüben szintén csatolni kell az OpenCV mappa elérési útvonalát.

\section{Fő program müködése}

A megfelelő header fájlok beolvasása után a fö program feladata, hogy az inputként kapott videófájlt lebontsa frame-kre a további feldolgozás céljából. A videó elemzés és képfeldolgozáshoz az OpenCV cv.hpp, core.hpp, highgui.hpp és video.hpp header fájlai kerültek megnyitásra.

A videófájl beolvasása egy cvCapture típusú változóba történik, ami az OpenCV egy, a mozgóképek kezelésére szolgáló adattípusa.

$\mathrm{Az}$ így deklarált változóba a cvCreateFileCapture() függvényben megadott elérési útvonal alapján történik a beolvasás. A framek a cvQueryFrame() metódus segítségével „vágódnak ki” a videófelvételről. Feldolgozásuk egy ciklusban történik, itt azonban fontos megemlíteni, hogy a projekthez választott gép ugyan relatív erös hardware-el rendelkezik, de még így sem alkalmas az összes frame kezelésére egyidejüleg, ezért csak minden 10dik frame kerül elemzésre.

A videóból kivágott képek átméretezésre kerülnek, hogy a felesleges képterületek kiessenek a feldolgozás alól. Ez azért lehetséges, mivel a forgalomjelző táblák többnyire a jobb oldalon találhatóak, ezért elégséges, ha a képünk jobb részét vetjük elemzés alá. Ezt a cvSetImageROI() függvénynyel hajtjuk végre(Region of Interest). A framek IplImage strukturában vannak tárolva, ami az Intel Image Processing Library formátumnak felel meg. Egy framet 3 ilyen strukturában tároljuk, hogy a párhuzamos feldolgozás során mind a 3 képre külön meg tudjuk hívni az egyik elemző függvényt. A föprogramban a cikluson belül, minden egyes szálra meghívjuk az adott függvényt, valamint az azok által visszaadott képet egy elöre felrajzolt ablakban megjelenítjük. A párhuzamosság az <omp.h> header fájl segítségével valósítható meg. A program csak akkor jeleníti meg az ablakot, ha a függvény talált alakzatot, így is javítva a teljesítményt. A megjelenítendő ablakok a cvShowWindow metódussal jelennek meg a lépernyön, amíg a cvMoveWindow funkcióval a paraméterként megadott $\mathrm{x}$, y koordinátákra irányíthatjuk azokat.

A futás végén ezek az ablakok, illetve a foglalt memória helyek egy gombnyomásra lebontódnak és felszabadulnak.

\section{Teljesítmény és működés}

A program egy 5 perces videofelvétel használatával lett tesztelve, amely során kisebb nagyobb hibával ismerte fel a különböző közlekedési táblákat. Megfigyelhető, hogy a video kis felbontása ellenére, és hogy folyamatosan bontódnak le a képek az 5 perc végére a program így is több mint 2GB memóriát használ fel. Emellett a processzor kihasználtsága nem emelkedett $25 \%$ (2,50 GHz) felé. Ez a memória igény a video hosszával és felbontásával tovább nőhet.

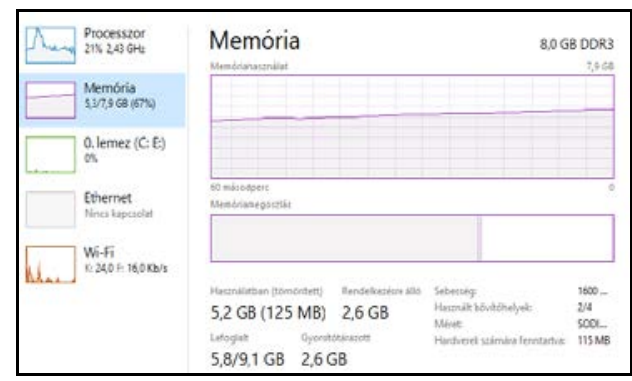

2. ábra. Teljesítmény a futás végén

A program a futás során a tesztfelvételről a közlekedési jelzőtáblák körülbelül 70\%-os (69.1\%) pontossági rátával ismerte fel és rajzolta körbe. Ez statisztikailag jó arány, amit a további algoritmusok bevonásával és nagyobb felbontású video anyagok felhasználásával tovább növelhető. Viszont ronthat a feldolgozási arányon, ha nagy sebesség mellett felvett videofelvételeket elemzünk le vele, mivel így nagy arányban közbe szólhat a kép elmosódása, valamint 
az autóban és a környezetben megjelenő csillogások is.

Az alábbi képeken látható, hogy a program futásakor a megjelenő ablakok a cvMoveWindow() metódusban paraméterként beállított $\mathrm{x}$ és y koordinátákon jelennek meg, valamint megtörténik a körberajzolás is.

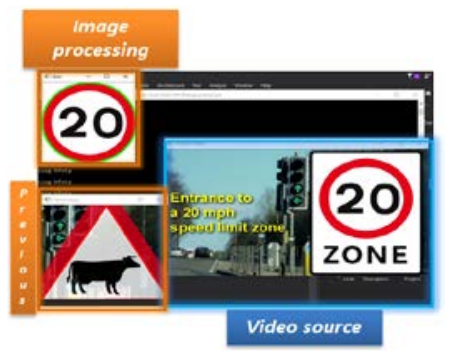

3. ábra. Test II.

\section{6. Összegzés}

Feladatunk eredményeként a közúti jelzőtábla felismerő szoftver elkészült. A program az elérési úton megadott videót elemzi, adott pontossági rátával felismeri, és kis ablakokban megjeleníti a mozgóképen látható jelzőtáblákat a felhasználónak.

A tervezés során felmerült, hogy a jelenlegi generációs hardware eszközök már rendelkeznek komoly számítási kapacitással, így egy Rapsberry PI 3 -as is alkalmas lehet paraméterei révén „redukált” képelemzési feladat ellátására.

További fejlesztési lehetőség lehetne, ha a szoftver, olyan szintet érne el, amellyel már felhasználhatóvá válna egy fejlesztésben lévő önjáró traktor részegységeként is.

\section{Köszönetnyilvánítás}

A publikáció elkészítését az EFOP-3.6.1-16-201600022 számú projekt támogatta. A projekt az Európai Unió támogatásával, az Európai Szociális Alap társfinanszírozásával valósult meg.

\section{Szakirodalmi hivatkozások}

[1] Waymo:,https://waymo.com/ontheroad/ (2017)

[2] Kichun Jo, Junsoo Kim, Dongchul Kim, Myoungho Sunwoo: Development of Autonomous Car-Part I: Distributed System Architecture and Development Process, IEEE
Transactions on Industrial Electronics 61(12):7131-7140, December 2014

[3] Matthew Russel, Scott Fischaber, OpenCV based road sign recognition on Zynq, Industrial Informatics (INDIN), 11th IEEE International Conference, 2013.

[4] C. Y. Fang, C. S. Fuh, P. S. Yen, S. Cherng, and S. W. Chen, An Automatic Road Sign Recognition System based on a Computational Model of Human Recognition Processing, Computer Vision and Image Understanding, Vol. 96, Issue 2 (November 2004), 237-268.

[5] Freemake Video Converter, (2017, May 14). http://www.freemake.com/hu/downloads/

[6] OpenCV, http://opencv.org/releases.html (2017).

[7] C. Bahlmann, Y. Zhu, V. Ramesh, M. Pellkofer, T. Koehler, A System for Traffic Sign Detection, Tracking, and Recognition Using Color, Shape, and Motion Information, Proceedings of the 2005 IEEE Intelligent Vehicles Symposium, Las Vegas, 6-8.06.2005.

[8] H. X. Liu, and B. Ran, Vision-Based Stop Sign Detection and Recognition System for Intelligent Vehicle, Transportation Research Board (TRB) Annual Meeting Jan. 7-11, 2001.

[9] Rapsberry PI3 specifications, https://www.raspberrypi.org/products/raspber ry-pi-3-model-b/ (2017, May 14).

[10] BoofCV, http://boofcv.org/notwiki/images/ benchmark_surf/overall_all_speed.gif (2017).

[11] G. Husi, T. I. Erdei, Zs. Molnár, A Novel Design of an Augmented Reality Based Navigation System \& its Industrial Applications, 15. IMEKO TC10 - Technical Diagnostics in Cyber-Physical Era Budapest, 6-7.06.2017.

[12] G. Husi, Minöségmenedzsment-rendszerek módszereinek alkalmazása a Magyar Köztársaság Rendörségénél, Megjelenés/Fokozatszerzés éve: 2006, 120.

[13] A. Husam, A. S. Adila, Zs. Molnár, T. I. Erdei, G. Husi, Reviewing the notable progress of effective techniques in the development of stroke hand rehabilitation" XXII. FMTÜ, 2017.

[14] N. C. Obinna, T. I. Erdei, Zs. Molnár, G. Husi, LabVIEW Motion Planning and Tracking of an Industrial Robotic Manipulator (KUKA KR5 arc): Design, Modelling, and Simulating the Robot's Controller Unit, XXII. FMTÜ, 2017.

[15] T. I. Erdei, Zs. Molnár, N. C. Obinna, G. Husi, AGV cyber physical navigation system, XXII. FMTÜ, 2017. 